\title{
Hemifacial Spasm and Recurrent Stroke Due to Vertebrobasilar Dolichoectasia Coexisting with Saccular Aneurysm of the Basilar Artery: A Case Report
}

\author{
Baziler Arter Sakküler Anevrizmaszyla Birlikte Vertebrobaziler \\ Dolikoektazi Nedeniyle Hemifasiyal Spazm ve Tekrarlayan Inme: \\ Bir Olgu Sunumu
}

Fang YUAN ${ }^{1}$, Ji LIN ${ }^{2}$, Lei DING ${ }^{1}$, You CHAO ${ }^{1}$, Liu WENKE ${ }^{1}$, Zhang HENG ${ }^{1}$

${ }^{1}$ West China Hospital, Sichuan University, Department of Neurosurgery, Cheng Du, China

${ }^{2}$ West China Hospital, Sichuan University, Department of Radiology, Cheng Du, China

Correspondence address: Zhang HENG / E-mail: zhangheng.cn@gmail.com

\begin{abstract}
We describe a patient presented with sequential events of hemifacial spasm, cerebral infarction and fatal subarachnoid hemorrhage. All of them are seemingly separate entities. Radiological examination revealed that the cause was vertebrobasilar dolichoectasia (VBD) coexisting with a giant saccular aneurysm of basilar artery. VBD is a dilatation and elongation of vertebral artery (VA) and basilar artery (BA) which is of different mechanism from saccular aneurysm. The condition is very rare and its progression may result in compression of brainstem and cranial nerves, ischemic and/or hemorrhagic stroke. The treatment of such condition is difficult and further research on the risk stratification of VBD for predicting stroke. Close monitoring and aggressive surgical interventions might be needed for high-risk patients.
\end{abstract}

KEYWORDS: Hemifacial spasm, Stroke, Vertebrobasilar dolichoectasia, Aneurysm

öz

Arka arkaya hemifasiyal spazm, serebral enfarktüs ve ölümcül subaraknoid kanama olaylarıyla gelen bir hastayı tanımlıyoruz. Bunların tümü ayrı olaylar gibi görünüyordu. Radyolojik inceleme nedenin baziler arterin dev bir sakküler anevrizmasıyla birlikte vertebrobaziler dolikoektazi (VBD) olduğunu gösterdi. VBD, vertebral arter (VA) ve baziler arterin (BA) dilatasyonu ve uzamasıdır ve mekanizması sakküler anevrizmadan farklıdır. Bu durum çok nadirdir ve ilerlemesi beyin kökü ve kraniyal sinirlerin kompresyonu ve ayrıca iskemik ve/veya hemorajik inmeye neden olabilir. Tedavisi zordur ve inme gelişmesini öngörmek açısından VBD risk katmanlandırması için daha fazla araştırma gereklidir. Yüksek riskli hastalarda yakından izleme ve agresif cerrahi girişim gerekebilir.

ANAHTAR SÖZCÜKLER: Hemifasiyal spazm, İnme, Vertebrobaziler dolikoektazi, Anevrizma

\section{BACKGROUND}

Hemifacial spasm (HFS) is most commonly caused by compression of the facial nerve root exit zone (RExZ) by a vascular loop. The resulting demyelination and focal ectopic excitation cause bursts of muscle activity on one side of the face. Brain stroke is a common disease and suffering from consecutive ischemic and hemorrhagic stroke seems irrelevant to HFS. In the current report we describe a patient presented with sequential events of hemifacial spasm, cerebral infarction and fatal hemorrhage due to vertebrobasilar dolichoectasia (VBD) coexisting with saccular aneurysm of basilar artery, and we discuss the monitoring and treatment of such condition.

\section{CASE PRESENTATION}

A 68-year-old man presented with a 4-year history of intermittent, involuntary muscle spasms involving the left part of his face. About one month before admission, he presented with acute onset limb weakness and blurred vision lasting for about 5 hours. On admission, neurological examination revealed left HFS. He was a current smoker (10/day) and alcohol abuser ( $1400 \mathrm{~mL} / \mathrm{wk}$ of pure ethanol) without history of hypertension, diabetes or hyperlipidemia.

MRI demonstrated both bilateral basal ganglia and right occipital lobe infarcts (Figure 1A). Both Magnetic resonance angiography (MRA) and computed tomographic angiography (CTA) demonstrated a marked VBD and a large saccular 
aneurysm of basilar artery (Figure 1B-G). The tortuous vertebrobasilar vessels elongated and enlarged over their entire course (diameter $6 \mathrm{~mm}$ ), compressed the left pons and impinged on the left side of the caudal pons in the root exit zone for the facial nerve (Figure 1C). There was a giant saccular aneurysm with plaque (Figure 1B) of basilar artery (diameter $10.6 \mathrm{~mm}$ ) located in the ventral pons. After discussion with the patient, the decision was made not to surgically intervene due to its potential complications. Two months after discharge, the patient presented with intermittent headache and elevated blood pressure $(180 / 100 \mathrm{mmHg})$ for a week and died suddenly due to subarachnoid hemorrhage (SAH).

\section{DISCUSSION}

Hemifacial spasm is a common disease with wide range of aetiologies. The causes of hemifacial spasm are listed in Table I (3). The commonest reason is vascular compression, of which the VBD is rare. VBD is ectasia, elongation, and tortuosity of the vertebrobasilar artery, the prevalence of intracranial dolichoectasia is approximately from $0.06 \%$ to $5.8 \%$ in the general population (5). Widely accepted criteria was diameter $>4.5 \mathrm{~mm}$ in any location along its course (10). The clinical manifestations include posterior circulation transient ischemic attacks (TIA) or infarction, deep lacunar infarction, intracranial hemorrhage, compression of brainstem and cranial nerves (5).

VBD is also classified as one of vertebrobasilar nonsaccular intracranial aneurysms (1), the progression of VBD is associated with a high risk of hemorrhage and even death $(1,2,6,7,8)$. Saccular aneurysm of basilar artery is very rare and of totally different pathogenesis from nonsaccular intracranial aneurysm. To our knowledge, the coexistence of two different types of aneurysms in basilar artery is very rare and has never been reported.

Treatment of VBD is in a dilemma. Antiplatelet therapy may be considered for the prevention of recurrent ischemic stroke in patients with current or previous ischemic stroke. However, for the potential risk of bleeding with severe forms of VBD (7), long-term use of combined antiplatelet agents or anticoagulants may not be recommended (7) especially in patient with unruptured aneurysm. Adequate control of blood pressure may be helpful to prevent ischemic or hemorrhagic stroke in patients with VBD (5). For the management of saccular aneurysm of basilar artery, endovascular surgery is more preferable with minimum invasiveness (4). Symptoms
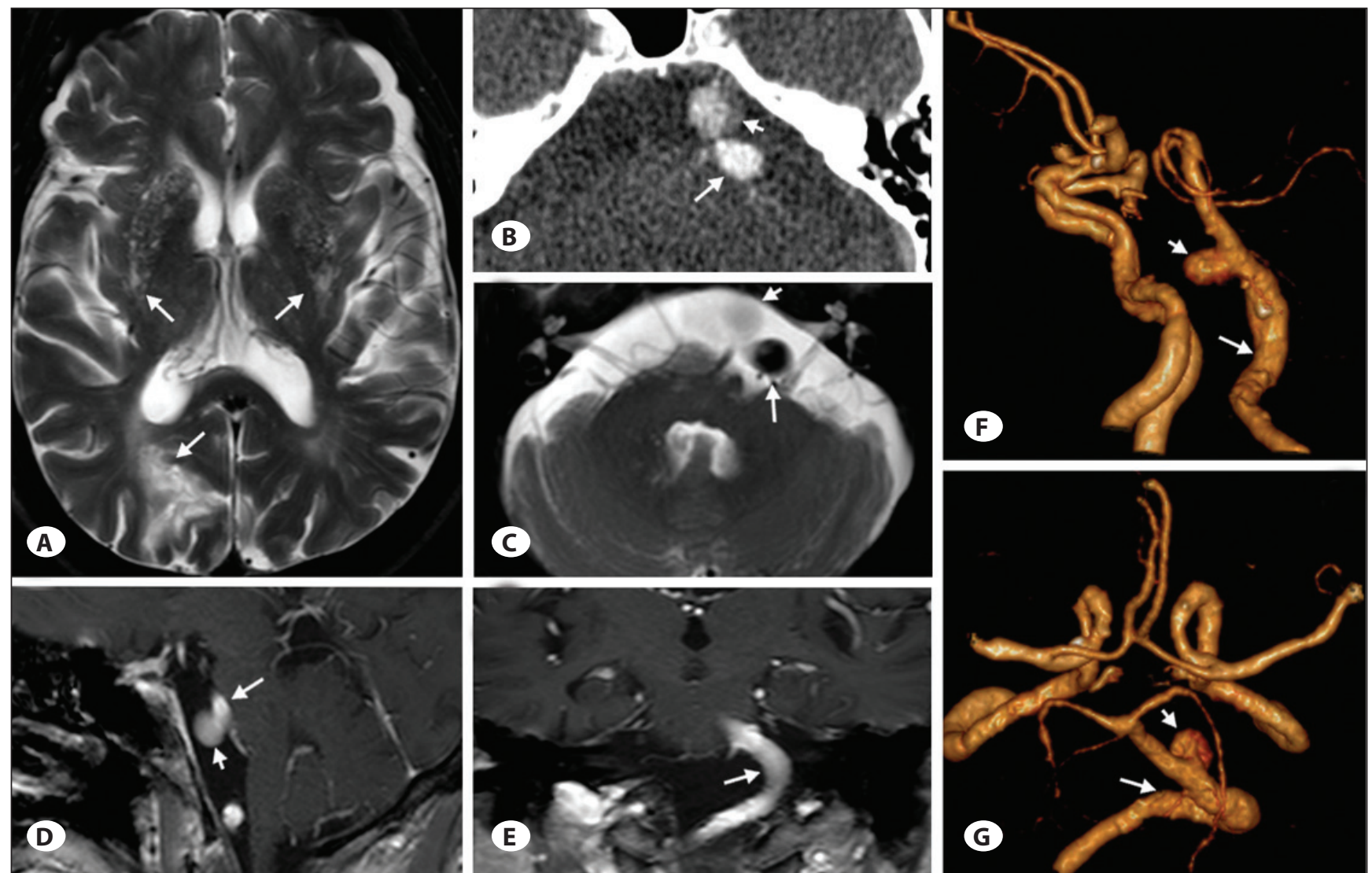

Figure 1: Axial (A) T2 Weighted MRI showing multiple infarcts of bilateral basal ganglia and right occipital lobe (arrows). Gadoliniumenhanced CT (B) and T2 Weighted MRI (C) showing VBD (arrow) compressed the left pons and the root exit zone for the facial nerve (C) and aneurysm (short arrow) with plaque (B). Sagittal (D) and coronal (E) MRA images and Volume rendering technique (VRT) images $(\mathbf{F}, \mathbf{G})$ showing VBD (arrow) and the aneurysm (short arrow). 
Table I: List of Causes of Hemifacial Spasm

$\begin{array}{ll}\text { Vessels } & \text { Artery, Vein, Developmental venous anomaly, Arterivenous malformation, Aneurysm, Pontine infarction, VBD } \\ \text { Mass } & \begin{array}{l}\text { Epidermoid, Vestibular schwannoma, Lipoma, Arachnoid cyst, Meningioma, Cholesteatoma, Parotid gland } \\ \text { tumors, Fourth ventricle gangliolioma, Pontine glioma }\end{array} \\ \text { Trauma } & \text { Central or peripheral facial nerve trauma } \\ \text { Others } & \begin{array}{l}\text { Chari I malformation, Paget's disease, Multiple sclerosis, Hypothyroidism, Idiopathic intracranial hypertension } \\ \text { (pseudotumor cerebri), Trigeminal neuralgia (tic convulsif/tic douloureux) }\end{array}\end{array}$

caused by compression of facial nerve (hemifacial spasm) may be alleviated by decompressive surgery (9). However, due to their potential complications, such surgical treatments should be cautious. For the progression of VBD or aneurysm is associated with a high morbidity and mortality (8), close observation and follow-up neuroimaging is recommended to monitor the progression and the appearance of new ischemic or hemorrhagic lesions. However, the appropriate timing and modality of serial imaging studies, the timing of surgical intervention and how to intervene have been unclear.

This presented case suffered from sequential events of hemifacial spasm, cerebral infarction and fatal hemorrhage due to VBD coexisting with a giant saccular aneurysm of basilar artery. Further research is required to refine the risk stratification of VBD for predicting stroke. Close monitoring and aggressive surgical interventions might be needed for high-risk patients.

Consent: Written informed consent was obtained from the patient for publication of these case reports.

\section{Competing interests: None}

Authors' contributions: Yuan Fang drafted the manuscript. Lin Ji processed the images. Ding Lei, Chao You and Wenke Liu examined the patient. Heng Zhang examined the patient and helped to revise the manuscript. Both authors read and approved the final manuscript.

\section{Acknowledgment}

Conflict of interest statement: This work was undertaken at West China Hospital/Sichuan University, which exclusively received a portion of funding from the National Natural Science Foundation of China (No. 81001117).

\section{REFERENCES}

1. Flemming KD, Wiebers DO, Brown RD Jr, Link MJ, Huston J 3rd, McClelland RL, Christianson TJ: The natural history of radiographically defined vertebrobasilar nonsaccular intracranial aneurysms. Cerebrovasc Dis 20:270-279, 2005

2. Flemming KD, Wiebers DO, Brown RD Jr, Link MJ, Nakatomi $H$, Huston J 3rd, McClelland R, Christianson TJ: Prospective risk of hemorrhage in patients with vertebrobasilar nonsaccular intracranial aneurysm. J Neurosurg 101:82-87, 2004

3. Galvez-Jimenez N, Hanson MR, Desai M: Unusual causes of hemifacial spasm. Semin Neurol 21:75-83, 2001

4. Higa $\mathrm{T}$, Ujiie $\mathrm{H}$, Kato $\mathrm{K}$, Kamiyama $\mathrm{H}$, Hori $\mathrm{T}$ : Basilar artery trunk saccular aneurysms: Morphological characteristics and management. Neurosurg Rev 32:181-191; discussion 191, 2009

5. Kwon HM, Lee YS: Dolichoectasia of the intracranial arteries. Curr Treat Options Cardiovasc Med 13:261-267, 2011

6. Mangrum WI, Huston J 3rd, Link MJ, Wiebers DO, McClelland RL, Christianson TJ, Flemming KD: Enlarging vertebrobasilar nonsaccular intracranial aneurysms: Frequency, predictors, and clinical outcome of growth. J Neurosurg 102:72-79, 2005

7. Passero SG, Calchetti B, Bartalini S: Intracranial bleeding in patients with vertebrobasilar dolichoectasia. Stroke 36: 1421-1425, 2005

8. Passero SG, Rossi S: Natural history of vertebrobasilar dolichoectasia. Neurology 70:66-72, 2008

9. Perlmutter $\mathrm{DH}$, Petraglia $\mathrm{AL}$, Barbano $\mathrm{R}$, Schwalb JM: Microvascular decompression in patient with atypical features of hemifacial spasm secondary to compression by a tortuous vertebrobasilar system: Case report. Neurosurgery 66, E1212; discussion E1212, 2010

10. Smoker WR, Corbett JJ, Gentry LR, Keyes WD, Price MJ, McKusker S: High-resolution computed tomography of the basilar artery: 2. Vertebrobasilar dolichoectasia: Clinicalpathologic correlation and review. AJNR Am J Neuroradiol 7:61-72, 1986 